\title{
DIREITO DE FAMÍLIA NO TEMPO DO CÓDIGO CIVIL DE 1916 AO DE 2002 E ALÉM*
}

\author{
Giselda Maria Fernandes Novaes Hironaka**
}

Sumário: Introdução - 1. O Direito Civil de 1916 - 2. Relação entre as pessoas da família: homens, mulheres e filhos - 3. Casamento e o tratamento das entidades familiares - 4. Parentesco, filiação e guarda - Conclusão - Referências.

\section{INTRODUÇÃO}

O Direito é um fenômeno multifacetado, rico nos diversos ângulos possíveis de observação que ele oferece. Por ser algo construído sociologicamente, recebe a influência dos eventos que ocorrem na sociedade, assim como é constantemente

* Artigo derivado de palestra que proferi na Reunião Científica do Departamento de Direito Civil da Faculdade de Direito da Universidade de São Paulo (FADUSP), em comemoração ao centenário da vigência da legislação civil codificada, no auditório Goffredo da Silva Telles Junior, em 07 de dezembro de 2017, sob a presidência da Professora Titular Silmara Juny de Abreu Chinellato e sob a coordenação do Professor Titular Nestor Duarte. A palestra teve como título "Direito de Família e Direito das Sucessões na vigência do Código Civil de 1916". Na pesquisa histórica auxiliou-me Rommel Andriotti, que é mestrando em "Função Social do Direito" com concentração em Direito Civil pela FADISP, mestrando em "Efetividade do Direito" com concentração em Processo Civil pela PUC/SP e especialista em Direito Civil e Processo Civil pela EPD.

** Professora Titular da Faculdade de Direito da Universidade de São Paulo (FADUSP). Coordenadora Titular e Professora Titular do Programa de Mestrado e Doutorado da Faculdade Autônoma de Direito de São Paulo (FADISP). Coordenadora Titular da área de Direito Civil da Escola Paulista de Direito (EPD). Mestre, Doutora e Livre docente pela Faculdade de Direito da Universidade de São Paulo (FADUSP). Ex Procuradora Federal. Diretora Nacional do IBDFAM (região sudeste) e Diretora Nacional do IBDCivil (região sudeste). 
alterado pela evolução dos costumes de um povo. Por isso, pode-se dizer que o Direito também é construído historicamente. Essa relação não é unidirecional, mas recíproca, significando que é tanto possível aprender mais sobre Direito com a história como, também, é possível aprender mais sobre a história com o Direito.

A evolução legislativa do Direito de Família ocorrida entre os Códigos de 1916 e 2002 demonstram bem essa relação simbiótica a qual me refiro. Outros pilares do direito privado como o contrato, a propriedade e a responsabilidade civil possuem mutação muito mais vagarosa em termos históricos. Entendam-me: novas modalidades de contratos surgem, assim como novas responsabilidades, mas a estrutura, o cerne dessas categorias, é milenar. Uma coisa é surgir um novo tipo de contrato ou forma de contratar - eletronicamente, por exemplo -, outra totalmente diferente é haver uma inversão completa dos próprios postulados da categoria jurídica. O contrato, enquanto ideia, tem os mesmos contornos desde tempos imemoriais. Mas ao se dizer "direito de família”, essa palavra, a "família”, é concebida de forma totalmente diferente a depender do lugar e da época a que se refere.

Por isso, comparar o direito de família de uma e outra época não é apenas um exercício estritamente jurídico, mas também uma jornada cidadã, uma aventura histórica, um estudo da própria natureza humana e da evolução das coisas; isso porque, por detrás de cada mudança legislativa; veladas sob cada artigo que alterou regras, encontram-se mil histórias de pessoas como nós, que viveram, alegraram-se e sofreram, e suas experiências pessoais tocaram a muitos e também ao legislador, motivando-o a alterar as leis, na difícil (ou virtualmente impossível) missão de fazer a norma acompanhar os fatos.

Então, a ideia deste trabalho é esta: longe de pretender esgotar o tema, nem oferecer uma comparação completa artigo-por-artigo entre leis, quero apontar algumas das principais alterações na regulação do Direito de Família do último século, sobretudo relacionando o Código Civil de 1916 com o de 2002. Ao final, essa análise proporcionará, além da correlata bagagem jurídica, uma oportunidade rica para uma leitura sociológica e histórica da sociedade brasileira sob as lentes do Direito. Mais que isso, quem sabe, este artigo poderá fornecer a identificação de tendências legislativas iniciadas no início do século XX e que poderão se projetar para o futuro.

\section{O DIREITO CIVIL DE 1916}

Embora o Código de 1916 (CC/1916) seja oficialmente o primeiro Código Civil brasileiro, seria impensável supor que ele não teria sido precedido por um rico 
histórico de tentativas anteriores. Não me preocuparei com grandes digressões, resgatando períodos antigos de outras civilizações, pois isso me afastaria do objetivo deste artigo. Cabe-me, aqui, apresentar as principais referências que sejam imediatamente anteriores à Lei n. 3.071, de $1^{\text {o }}$ de janeiro de 1916 (CC/1916) e que mereçam menção. Ei-las:

1. Ordenações Filipinas;

2. Alvará de 9 de novembro de 1754 ;

3. Consolidação das Leis Civis de Teixeira de Freitas;

4. O Projeto de Nabuco de Araújo e o esboço de Teixeira de Freitas;

5. Projeto de Felício dos Santos;

6. Projeto de Coelho Rodrigues;

7. Consolidação de Carlos de Carvalho;

8. O Projeto de Beviláqua (que se tornaria o Código de 2016).

Traçando um panorama histórico desses diplomas normativos e projetos de lei, temos que, proclamada a independência brasileira em sete de setembro de 1822 , as leis portuguesas de direito privado permaneceram em vigor, já que o Brasil, enquanto país, acabara de nascer e ainda não havia legislado sobre essas matérias. As Ordenações Filipinas vigiam desde 1603, e assim permaneceriam por longo tempo, até serem substituídas pelo próprio Código Civil de 1916. Com o passar do tempo e com a edição de mais e mais leis civis, o compêndio de normas de direito privado se estendia em um intrincado emaranhado legislativo, com muitas leis esparsas incidindo sobre as mais diversas áreas do direito civil. Tudo isso era dificultado pela precariedade dos meios de comunicação da época, o que tornava árdua a tarefa de manter atualizado o conhecimento de quais normas estavam e não estavam em vigor. Daí a importância da Consolidação das Leis Civis de Teixeira de Freitas, civilista brilhante do oitocentismo brasileiro. Teixeira de Freitas entregou em 1858 uma consolidação de toda a legislação civil em vigor, trabalho muito aclamado e que facilitou em grande medida o labor jurídico da época.

Teixeira de Freitas seria chamado posteriormente pelo Ministro Nabuco de Araújo para escrever um Código Civil do Império, o que foi feito, mas o trabalho era muito avançado para seu tempo e recebeu duras críticas da comissão revisora. Desgostoso, Teixeira de Freitas resolveu abandonar o projeto, comunicando sua desistência ao então Ministro da Justiça, José de Alencar. É importante apontar que, embora referido esboço não tenha sido aproveitado imediatamente pelos 
brasileiros, certo é que serviu de inspiração para nossos países vizinhos, notadamente Argentina, Uruguai, Paraguai e, posteriormente, para o próprio Clóvis Beviláqua quando da elaboração de seu projeto.

Antes de o Brasil finalmente ter um Código Civil para chamar de seu, houve o Projeto de Joaquim Felício dos Santos; o de Coelho Rodrigues, este que foi o pai do Decreto n. $181^{1}$, que introduziu o casamento civil no Brasil (o casamento válido era apenas o religioso) e a consolidação de Carlos de Carvalho, dentre outros projetos e leis esparsas. Esses nomes são apenas aqui citados dadas as limitaçôes de espaço para narrar história tão vasta, apesar dos méritos de cada um deles.

Posteriormente, foi o Ministro Epitácio Pessoa quem convidou o jurista Clóvis Beviláqua para redigir um novo Projeto de Código Civil, projeto que foi bem-sucedido, dada a promulgação da Lei $3.071 \mathrm{em} \mathrm{10}$ de janeiro de $1916^{2}$.

Clóvis Beviláqua, além de ter se inspirado nos projetos de Coelho Rodrigues e Teixeira de Freitas, recorreu aos sistemas jurídicos francês (Code Napoléon de 1804), canônico, romano e outros códigos civis modernos (como o alemão e o suíço) na elaboração de seu projeto. O Código ficou marcado por representar a imagem do direito positivo daquele tempo: individualista e voluntarista. É bom lembrar que a população brasileira era essencialmente agrícola, conservadora e católica, de modo que o Código foi elaborado para refletir essas características sociais. No prefácio que, em 1928, Clóvis Beviláqua redigiu para a tradução francesa do Código Civil brasileiro, tradução esta elaborada por Goulé, Daguin e Tizac, ele observou, quanto às fontes dessa codificação, o seguinte:

O Código Civil brasileiro, inspirando-se no direito estrangeiro estudado na legislação e na doutrina, reflete imagem fiel da época em que foi publicado; ele fixa um momento de evolução jurídica mundial. Guarda, todavia, sua fisionomia original, tanto no aspecto técnico, quanto no social. Tecnicamente, é ele a criação própria dos jurisconsultos brasileiros que, desde Teixeira de Freitas e todos os que, com ele ou depois dele, emprestaram sua colaboração ao preparo do Código, todos formados pela cultura

1 BRASIL. União. Decreto n. 181, de 24 de janeiro de 1890. Rio de Janeiro: Governo provisório da República dos Estados Unidos do Brasil, 1890 (ano da publicação originária). Disponível em: <http://www2.camara.leg.br/legin/fed/decret/1824-1899/decreto-181-24-janeiro-1890-507282-publicacaooriginal-1-pe.html>. Acesso em: 10 de fevereiro de 2018.

2 BRASIL. União. Lei n. 3.071, de $1^{\circ}$ de janeiro de 1916 [CC/1916 - Código Civil]. Brasilia: Congresso Nacional, 1916 [ano da publicação originária]. Disponível in Portal da Legislação do Governo Federal. Disponível em: http://legislacao.planalto.gov. br/legisla/legislacao. nsf/Viw_Identificacao/lei\%203.071-1916? OpenDocument>. Acesso em: 27 de outubro de 2017. 
brasileira e esforçando-se em satisfazer os interesses da comunidade em cujo seio viviam, servindo-se dos meios que ela mesma lhes oferecia. Socialmente, o Código

Civil é a expressão exata e característica da sociedade brasileira atual. ${ }^{3}$

Haja vista o fato de que o Código Civil de 1916, nas palavras de Beviláqua, expressa precisamente a sociedade brasileira da época, então há de se averiguar o que dizia o Código em seu livro de Direito de Família para conhecer que sociedade era aquela. Para esse fim, examinarei apenas alguns aspectos do Livro I da parte Especial daquela codificação, o Direito de Família, do primeiro Código Civil brasileiro. Fiz o recorte em determinados assuntos que, penso, são os mais relevantes. Depois, tracei os principais marcos de cada tema até chegar na forma como se dá seu tratamento atualmente.

\section{RELAÇÃO ENTRE AS PESSOAS DA FAMÍLIA: HOMENS, MULHERES E FILHOS}

Em primeiro lugar, o Código Civil de 1916 tratava a família de forma hierarquizada e patriarcal, o que derivava diretamente de uma tradição greco-romana de prevalência do pai (homem) sobre a mulher, filhos, agregados e empregados do $\operatorname{lar}^{4}$. O poder era considerado algo essencialmente masculino, colocado na pessoa do homem, o "chefe" da sociedade conjugal, sendo que à mulher cabia a função de colaboraçã $o^{5}$. Mais que isso, determinava-se que a mulher, ao casar, assumiria a condição de "companheira, consorte e auxiliar" do marido nos encargos da família $^{6}$. Em outras palavras, a mulher era relegada a uma condição subalterna à do homem na vida do casal.

Isso ficava ainda mais evidente com a disposição do art. 233, inc. IV, do CC/1916, que determinava que o homem tinha o direito de autorizar ou não que a

3 BEVILÁQUA, Clóvis. Code civil des Éstats-Unis du Brésil; traduit et annoté par P. Goulé, C. Daguin e G. D’Ardenne de Tizac, Paris, Nationale, 1928, n. 29, p. 48-49 apud MOREIRA ALVES, José Carlos. Panorama do direito civil brasileiro: das origens aos dias atuais. Revista de Direito da Faculdade de Direito da Universidade de São Paulo (FADUSP). São Paulo: FADUSP, 1990? Disponível em <http://www.revistas.usp.br/rfdusp/article/viewFile/67220/69830 >. Acesso em: 18 de fevereiro de 2018.

$4 \mathrm{Na}$ verdade, essa era uma tradição de praticamente todas as culturas antigas, sendo a greco-romana aqui destacada simplesmente porque foram essas as civilizaçôes-berço das demais comunidades ocidentais que se seguiriam.

5 Art. 233. O marido é o chefe da sociedade conjugal, função que exerce com a colaboração da mulher, no interêsse comum do casal e dos filhos (arts. 240, 247 e 251).

6 Art. 240. A mulher assume, pelo casamento, com os apelidos do marido, a condição de sua companheira, consorte e auxiliar nos encargos da família (art. 324). 
mulher trabalhasse e tivesse uma profissão ${ }^{7}$, o que só seria alterado quase cinquenta anos depois, com a Lei n. 4.121, de $1962^{8}$.

Aliás, há de se lembrar que até 1962, a mulher casada era considerada relativamente incapaz, ao lado dos maiores de dezesseis e menores de vinte e um anos, dos pródigos e dos silvícolas 9 . Era algo muito curioso: a mulher era plenamente capaz após completar vinte e um anos, mas somente teria essa capacidade até casar. Após o matrimônio, as mulheres perdiam sua capacidade, voltando a serem consideradas como se menores fossem. E eis o dado mais curioso ainda: mesmo assim o casamento era tido como o sonho das mulheres!

Foi somente em 27 de agosto de 1962, com a publicação da Lei n. 4.121 (Estatuto da Mulher Casada), que as mulheres obtiveram a capacidade completa (a despeito de seu estado civil), a possibilidade de exercer poder familiar e a opção de exercer ou não profissão, sem precisar, para isso, de autorização do marido ${ }^{10}$.

Outra norma relevante do Código de 16 era a que determinava que a mulher seria obrigada a adotar o nome do marido, situação que só seria alterada em 1977 com a Lei n. $6.515^{11}$, que alterou o parágrafo único do art. 240 do CC/1916 para inserir a expressão "poderá acrescer aos seus os apelidos do marido", quando antes essa inclusão era automática e compulsória. Vale já adiantar que o Código Civil de

7 Art. 233. O marido é o chefe da sociedade conjugal. Compete-lhe: I. A representação legal da família. II. A administração dos bens comuns e dos particulares da mulher, que ao marido competir administrar em virtude do regime matrimonial adaptado, ou do pacto antenupcial (arts. 178, $\$ 9^{\circ}$, n. I, c, 274, 289, n. I, e 311). III. direito de fixar e mudar o domicílio da família (arts. 46 e 233, n. IV). (Vide Decreto do Poder Legislativo n. 3.725, de 1919). IV. O direito de autorizar a profissão da mulher e a sua residência fora do tecto conjugal (arts. 231, n. II, 242, n. VII, 243 a 245, n. II, e 247, n. III). V. Prover à manutenção da família, guardada a disposição do art. 277", op. cit.

8 BRASIL. Uniāo. Lei n. 4.121, de 27 de agosto de 1962, que dispõe sobre a situação jurídica da mulher casada. Brasília: Congresso Nacional, 1962 (data da publicação originária). Disponível em: <http://www.planalto.gov. br/Ccivil_03/leis/1950-1969/L4121.htm\#art1>. Acesso em: 9 de fevereiro de 2018.

9 Art. $6^{o}$ São incapazes, relativamente a certos atos (art. 147, n. 1), ou à maneira de os exercer: I. Os maiores de dezesseis e menores de vinte e um anos (arts. 154 a 156). II. As mulheres casadas, enquanto subsistir a sociedade conjugal. III. Os pródigos. IV. Os silvícolas. Parágrafo único. Os silvícolas ficarão sujeitos ao regime tutelar, estabelecido em leis e regulamentos especiais, e que cessará à medida de sua adaptação", op. cit. BRASIL, Lei 4.121, de 1962, op. cit.

11 Lei n. 6.515, art. 50, cf. BRASIL. União. Lei n. 6.515, de 26 de dezembro de 1977, que regula os casos de dissolução da sociedade conjugal e do casamento, seus efeitos e respectivos processos e dá outras providências. Brasília: Congresso Nacional, 1977 (ano da publicação originária). Disponível em: <http://www.planalto.gov. br/ccivil_03/leis/16515.htm>. Acesso em: 14 de fevereiro de 2018. 
2002 tornou opcional a adoção do sobrenome do consorte tanto para o homem como para a mulher ${ }^{12}$.

Finalmente, deu-se a promulgação da Constituição brasileira de $1988^{13}$, um marco para o direito de família brasileiro porque elaborada seguindo valores modernos e alinhados com a mentalidade da época, o que, no que tange ao direito de família, significou uma principiologia muito mais pluralista, flexível e tolerante. A Constituição Federal de 1988 foi referencial em termos de atualização da norma frente a todas as manifestações sociais que aquela época exalava. O que se observa com mais nitidez é que o caminho entre 1916 e 1988 foi de um declínio da família patriarcal. Esta foi sendo progressivamente mal vista até chegar ao ponto em que a distinção entre os direitos de homens e mulheres se tornou inadmissível e, por isso, inconstitucional. Nesse sentido, ao ponto de ser repetitiva, a Constituição Federal de 1988 determina que haja isonomia no tratamento entre homens e mulheres tanto no art. $5^{\circ}$, inc. I, como também no art. $226, \$ 5^{\circ}$, justamente para ressaltar que não se deve discriminar um sexo em prol do outro, na tentativa de eliminar de vez todo o ranço preconceituoso trazido pelas legislações de outrora, cujos efeitos se viam tão presentes na sociedade e no próprio Código Civil de 1916, como já visto.

A promulgação da Constituição foi particularmente importante de um ponto de vista hermenêutico porque o sistema já convivia novamente com muitas normas esparsas, além do fato de que os códigos e a própria Constituição anterior já tinham se tornado colchas de retalhos repletas de alterações, de modo que não havia mais uma harmonia sistemática. A Carta Política de 1988 teve, então, o mérito de reunificar o sistema, além de ter elegido um rol de novos valores para o ordenamento jurídico brasileiro, que são aplicáveis diretamente às relações entre os particulares. Assiste-se, nesse sentido, ao fenômeno da constitucionalização do direito privado $^{14}$, que desencadeia um alastramento dos valores constitucionais a todas as relações privadas, inclusive as relações familiares.

12 Conforme o CC/2002, art. 1.565, $\$ 1^{\circ}$, que diz "qualquer dos nubentes, querendo, poderá acrescer ao seu o sobrenome do outro".

13 BRASIL. Constituição da República Federativa do Brasil de 1988 [CF/88]. Brasília: Congresso Nacional (Poder Constituinte), outubro de 1988. Disponível no Portal da Legislação do Governo Federal: <http://www.planalto.gov. br/ccivil_03/constituicao/constituicao.htm>. Acesso em: 11 de julho de 2017.

14 V. PERLINGIERI, Pietro. O direito civil na legalidade constitucional. Tradução de Maria Cristina De Cicco. Rio de Janeiro: Renovar, 2008; TEPEDINO, Gustavo; BARBOZA, Heloisa Helena; MORAES, Maria Celina Bodin de. Código Civil interpretado conforme a Constituição da República. 2. ed., rev. e atual. Rio de Janeiro: Renovar, 2007, p. 213; e também AFONSO DA SILVA, Virgílio. A constitucionalização do direito: os direitos fundamentais nas relaçôes entre particulares. São Paulo: Malheiros, 2014. 
O atual Código Civil- Lei n. 10.406/2002 ${ }^{15}$ - é, evidentemente, uma importante baliza para o direito de família, mas trouxe menos inovaçōes do que poderia ao tempo de sua publicação. Isso se deve ao fato, bem lembrado por Luciano Silva Barreto $^{16}$, de que o Código Civil de 2002 foi aprovado mais de 20 anos depois de quando ele foi pensado. E realmente, recordo-me que assisti a tudo isso de perto. Tive a oportunidade de estudar o Projeto 634-B, que seria posteriormente o atual CC/2002, ainda em 1973, em crédito do saudoso Professor Rubens Limongi França denominado Institutos de Direito Civil à luz do Projeto 634-B, o que consistiu em parte de meu mestrado na Faculdade de Direito da Universidade de São Paulo (FADUSP). Logo, sou testemunha ocular de que a tramitação do Código foi assaz extensa e atrasada por muitos percalços. Evidentemente que o projeto foi sendo atualizado conforme certas alterações legislativas ocorriam e a sociedade evoluía, mas as principais novidades que ele traria foram, por assim dizer, deixando de ser novidades à medida que outras leis tratavam daqueles assuntos que seriam regulados pelo Código vindouro. Ainda assim, o CC/2002 foi uma enorme evolução, principalmente quando comparado ao seu precursor, e a falta inicial de arrojo em seus dispositivos foi sendo consertada pelo legislador, pela doutrina e pela jurisprudência no decorrer dos anos, que vêm constantemente atualizando a interpretação do Código para que reflita da melhor forma os interesses da coletividade dado o contexto atual.

Bom exemplo disso foi a recente declaração da inconstitucionalidade do art. 1.790 do Código Civil, que fazia diferenciação entre o regime sucessório do cônjuge e do companheiro. Recebi com grande satisfação a notícia do julgamento do RE n. 646.721/RS ${ }^{17}$ e do RE n. 878.694/MG ${ }^{18}$, pois assisti, em 2017, à consagração da

15 BRASIL. (União). Lei n. 10.406, de 10 de janeiro 2002 [CC/2002 - Código Civil]. Brasilia: Congresso Nacional, 2002 [ano da publicação originária]. Disponível in Portal da Legislação do Governo Federal. 2002. Disponível em: <http://www.planalto.gov. br/ccivil_03/leis/2002/ L10406.htm>. Acesso em: 19 de junho de 2017.

16 BARRETO, Luciano Silva. Evolução histórica e legislativa da família. Série Aperfeiçoamento de Magistrados n. 13 - 10 Anos do Código Civil - Aplicação, Acertos, Desacertos e Novos Rumos, v. I. [s.l.: s.n. ], 2012?, p. 213.

17 BRASIL. Supremo Tribunal Federal (STF). Recurso Extraordinário (RE) n. 646.721/RS. Relator: Ministro Marco Aurélio de Mello; Relator para o acórdão: Ministro Roberto Barroso. Brasília: STF, 11 de setembro de 2017. Disponível em: <http://www.stf.jus.br/portal/jurisprudencia/listarJurisprudencia.asp?s1=\%28646721\%2ENUME\%2E+OU+646721\%2EACMS\%2E\%29\&base =baseAcordaos\&url=http://tinyurl.com/j9y92gj>. Acesso em: 18 de fevereiro de 2018.

18 "Ementa: Direito constitucional e civil. Recurso extraordinário. Repercussão geral. Inconstitucionalidade da distinção de regime sucessório entre cônjuges e companheiros. 1. A Constituição brasileira contempla diferentes formas de família legítima, além da que resulta do casamento. Nesse rol incluem-se as famílias formadas mediante união estável. 2. Não é legítimo desequiparar, para fins sucessórios, os cônjuges e os companheiros, isto é, a família formada 
tese que escrevi para o concurso de Professor Titular da FADUSP, em 2010, e que se tornaria meu Morrer e Suceder ${ }^{19}$.

\section{CASAMENTO E O TRATAMENTO DAS ENTIDADES FAMILIARES}

Analisar o casamento também é um excelente exercício jurídico, histórico e sociológico em termos de análise das diferentes sociedades no tempo. Quando o Código Civil de 1916 foi publicado, a única entidade familiar reconhecida foi aquela formada pelo casamento, em clara positivação das tradições religiosas dominantes ${ }^{20}$.

pelo casamento e a formada por união estável. Tal hierarquização entre entidades familiares é incompatível com a Constituição de 1988. 3. Assim sendo, o art. 1790 do Código Civil, ao revogar as Leis ns. 8.971/94 e 9.278/96 e discriminar a companheira (ou o companheiro), dando-lhe direitos sucessórios bem inferiores aos conferidos à esposa (ou ao marido), entra em contraste com os princípios da igualdade, da dignidade humana, da proporcionalidade como vedação à proteção deficiente, e da vedação do retrocesso. 4. Com a finalidade de preservar a segurança jurídica, o entendimento ora firmado é aplicável apenas aos inventários judiciais em que não tenha havido trânsito em julgado da sentença de partilha, e às partilhas extrajudiciais em que ainda não haja escritura pública. 5. Provimento do recurso extraordinário. Afirmação, em repercussão geral, da seguinte tese: "No sistema constitucional vigente, é inconstitucional a distinção de regimes sucessórios entre cônjuges e companheiros, devendo ser aplicado, em ambos os casos, o regime estabelecido no art. 1.829 do CC/2002". (RE 878694, Relator (a): Min. ROBERTO BARROSO, Tribunal Pleno, julgado em 10/05/2017, PROCESSO ELETRÔNICO DJe-021 DIVULG 05-02-2018 PUBLIC 06-02-2018)", conforme: BRASIL. Supremo Tribunal Federal (STF). Recurso Extraordinário (RE) n. 878.694/MG. Relator: Ministro Roberto Barroso. Brasília: STF, 6 de fevereiro de 2018. Disponível em: <http://www. stf.jus.br/portal/jurisprudencia/listarJurisprudencia.asp?s1=\%28878694\%2ENUME\%2E+ $\mathrm{OU}+878694 \% 2 \mathrm{EACMS} \% 2 \mathrm{E} \% 29$ \&base = baseAcordaos \&url=http://tinyurl.com/he2a4o4>. Acesso em: 18 de fevereiro de 2018.

19 Ver, dentre outras passagens sobre a diferenciação do regime sucessório entre cônjuge e companheiro: "esse distinto tratamento que vem desde as páginas do direito de família, no Código Civil, repercute desastrosamente no regramento sucessório dessas mesmas pessoas, causando inquietude e, quiçá, insegurança jurídica. Essa questão é tormentosa, sem dúvida, e tem levado os estudiosos do direito às mais diversas elucubraçôes, no sentido de procurar desvendá-la. Pessoalmente, não sabemos bem como responder, a não ser imaginando que o fundo de justificação tenha sido uma dose de preconceito descabido, senão abominável, que tocou, infelizmente, o legislador brasileiro. No nosso sentir, não há outra solução melhor que a de se buscar mudar, e logo, essa retrógrada e descompassada legislação, de molde a poder se atribuir, ao companheiro, direito minimamente idêntico ao direito que se atribui ao cônjuge, no que diz respeito - ao menos naquilo que nos toca dizer, neste estudo - às regras relativas ao direito de herdar", conforme HIRONAKA, Giselda Maria Fernandes Novaes. Morrer e suceder: passado e presente da transmissão sucessória concorrente. 2. ed. rev. São Paulo: RT, 2014, p. 429-430.

20 Além disso, o Código seguia a ideia da própria Constituição vigente à época, a de 1891, que determinava: “art. 72. $\$ 4^{\circ}-$ A República só reconhece o casamento civil, cuja celebração será 
O casamento, em regra, era indissolúvel, deveria valer para toda a vida, e o regime legal para os casamentos era o da comunhão universal de bens ${ }^{21}$. $\mathrm{O}$ art. 315 do Código Civil ${ }^{22}$ dizia que a sociedade conjugal terminava somente pela morte de um dos cônjuges, pela nulidade ou anulação do casamento, ou via ação de desquite, que por sua vez só poderia ser ajuizada, nos termos do art. $317^{23}$, se houvesse adultério, tentativa de morte, sevícia ${ }^{24}$, injúria grave ou abandono voluntário do lar conjugal por ao menos dois anos consecutivos. Aliás, o adultério deixaria de ser motivo de desquite, nos termos do art. $319^{25}$, se o autor (da ação de desquite) houvesse concorrido para que o réu o cometesse, ou ainda se o cônjuge inocente perdoasse o culpado, o que se presumiria haver ocorrido se aquele coabitasse com esse após ciência do fato.

Em 1977, houve a edição da Emenda Constitucional (EC) n. 09², que modificou a Constituição Federal da República Federativa do Brasil de $1967^{27}$ para possibilitar a dissolução do casamento mediante divórcio, desde que houvesse prévia separação judicial por mais de três anos. No mesmo ano foi editada a Lei $6.515^{28}$, que

gratuita”, cf. BRASIL. União. Constituição da República dos Estados Unidos do Brasil, de 24 de fevereiro de 1891. Rio de Janeiro: Congresso Constituinte, 1891 (data da publicação originária). Disponível em: <https://legislacao.planalto.gov. br/legisla/legislacao.nsf/viwTodos/4ed91 893cbdd0e10032569fa0074213f? OpenDocument\&Highlight $=1, \&$ AutoFramed $>$. Acesso em: 10 de fevereiro de 2018.

21 O art. 258 do Código Civil de 1916 diz: "Art. 258. Não havendo convenção, ou sendo nula, vigorará, quanto aos bens, entre os cônjuges, o regime da comunhão universal”, op. cit.

22 CC/1916, "Art. 315. A sociedade conjugal termina: I. Pela morte de um dos cônjuges. II. Pela nulidade ou anulação do casamento. III. Pelo desquite, amigável ou judicial. Parágrafo único. O casamento valido só se dissolve pela morte de um dos conjugues, não se lhe aplicando a preempção estabelecida neste Código, art. 10, Segunda parte”, op. cit.

23 CC/1916, "Art. 317. A ação de desquite só se pode fundar em algum dos seguintes motivos: I. Adultério; II. Tentativa de morte; III. Sevicia, ou injuria grave”, op. cit.

24 Refere-se a maus-tratos, crueldade, tortura física e mental, martírio.

25 "Art. 319. O adultério deixará de ser motivo para desquite: I. Se o autor houver concorrido para que o réu o cometesse (Vide Decreto do Poder Legislativo n. 3.725, de 1919). II. Se o cônjuge inocente lhe houver perdoado. Parágrafo único. Presume-se perdoado o adultério, quando o cônjuge inocente, conhecendo-o, coabitar com o culpado", op. cit.

26 BRASIL. Emenda Constitucional (EC) n. 9, de 28 de junho de 1977. Brasília: Mesas da Câmara dos Deputados e do Senado Federal, 1977 (ano da publicação originária). Disponível em: <http://www.planalto.gov. br/ccivil_03/constituicao/Emendas/Emc_anterior1988/emc0977.htm>. Acesso em: 20 de fevereiro de 2018.

27 BRASIL. Constituição da República Federativa do Brasil de 1967 (CF/67). Brasília: Constituinte, 1967 (ano da publicação originária). Disponível em: <http://www.planalto.gov. br/ccivil_03/constituicao/constituicao67.htm>. Acesso em: 08 de fevereiro de 2018.

28 BRASIL. União. Lei n. 6.515, de 26 de dezembro de 1977, que regula os casos de dissolução da sociedade conjugal e do casamento, seus efeitos e respectivos processos e dá outras providências. 
trouxe diversos avanços, dentre os quais a possibilidade de ação direta de divórcio, cabível contanto que houvesse cinco anos ou mais de separação de fato. Essa mesma lei também foi a responsável por trocar o regime legal de bens do universal para o Regime Parcial de Bens ${ }^{29}$. Então, desde 1977 que a comunhão parcial é o regime patrimonial padrão para casamentos no Brasil.

Após, a Constituição Federal de 1988 trouxe enorme avanço para o tema. São méritos de nossa Carta Magna a proteção constitucional das entidades familiares não fundadas no casamento $\left(\mathrm{CF} / 88\right.$, art. $\left.226, \$ 3^{\circ}\right)$; as famílias monoparentais

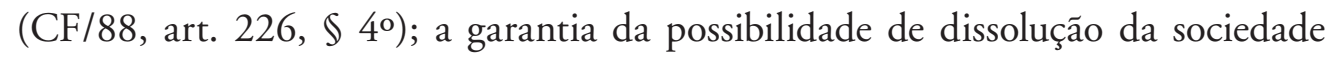
conjugal, independentemente de culpa (CF/88, art. 226, $\left.\$ 6^{\circ}\right)$; o planejamento familiar, voltado para os princípios da dignidade da pessoa humana e da paternidade responsável $\left(\mathrm{CF} / 88\right.$, art. $\left.226, \$ 7^{\circ}\right)$; além da previsão de ostensiva intervenção estatal no núcleo familiar no sentido de proteger seus integrantes e coibir a violência doméstica $\left(\mathrm{CF} / 88\right.$, art. $\left.226, \$ 8^{\circ}\right)$.

Hoje, consideradas as evoluçôes mais recentes na matéria, já se admitem ainda mais entidades familiares, como aquela formada pela união de pessoas do mesmo $\operatorname{sexo}^{30}$ e a que resulta do reconhecimento da dupla paternidade ${ }^{31}$. Isso revela uma tendência de flexibilização dos critérios para a caracterização de uma entidade como sendo familiar, e essa tendência não tem indícios de parar. Nesse sentido, já se fala em reconhecimento das famílias pluriafetivas, por exemplo.

\section{PARENTESCO, FILIAÇÃO E GUARDA}

No início do século XX, fazia-se diferenciação entre filhos legítimos, ilegítimos, naturais e adotivos ${ }^{32}$. Deveras, no art. 377 do Código Civil de 1916 consta que "quando o adotante tiver filhos legítimos, legitimados ou reconhecidos, a relação de adoção não envolve a de sucessão hereditária”"33. Apenas em 1949 foi editada

Brasília: Congresso Nacional, 1977 (ano da publicação originária). Disponível em: <http:// www.planalto.gov. br/ccivil_03/leis/16515.htm>. Acesso em: 14 de fevereiro de 2018.

29 Conforme art. 50, item 7, que alterou o art. 258, caput, do Código Civil de 1916, Ibidem.

30 V. ADPF n. 132 e ADI n. 4.277, do STF.

31 V. RE 898.060, julgado pelo STF.

32 Por exemplo, o art. 183, inc. I, dizia: “art. 183. Não podem casar (arts. 207 e 209): I. Os ascendentes com os descendentes, seja o parentesco legítimo ou ilegítimo, natural ou civil”. Outro exemplo: "Art. 332. O parentesco é legitimo, ou ilegítimo, segundo procede, ou não de casamento; natural, ou civil, conforme resultar de consanguinidade, ou adoção".

33 CC/1916, art. 377, cf. BRASIL. União. Lei n. 3.071, de $1^{\circ}$ de janeiro de 1916 [CC/1916 - Código Civil]. Brasilia: Congresso Nacional, 1916 [ano da publicação originária]. Disponível in 
a Lei n. 883, que dispõe sobre o reconhecimento de filhos ilegítimos ${ }^{34}$, que possibilitou aos filhos antes tidos por "ilegítimos" a obtenção de direito a alimentos e herança, consistindo em importante passo para o reconhecimento da igualdade entre os filhos, não importando sua origem. Isso seria sacramentado na própria Constituição de 1988, que determina, no artigo 227, $\$ 6^{\circ}$ : "Os filhos, havidos ou não da relação do casamento, ou por adoção, terão os mesmos direitos e qualificações, prolbidas quaisquer designações discriminatórias relativas à filiação"35.

Com relação à guarda, merecia-a aquele não fosse o culpado na ação de desquite, ou seja, não se pensava no que seria melhor para a criança ou adolescente, mas sim na averiguação da culpa pelo término do relacionamento ${ }^{36}$. Isso transformava o "ficar com a criança" em um verdadeiro prêmio para quem vencesse a ação, motivando o litígio, a troca gratuita de acusações mútuas e o recrudescimento do tratamento entre os envolvidos. A criança se tornava mero objeto de disputa, de modo que seus interesses não apenas ficavam em segundo plano como, mais que isso, poderiam ser completamente ignorados. Infelizmente, essa penosa situação durou muito tempo.

O regramento jurídico da guarda e da adoção teria um grande avanço no Brasil após a Convenção da Organização das Nações Unidas (ONU) sobre os direitos da criança, realizada em 20 de novembro de 1989 em Nova Iorque e internalizada no Brasil por meio do Decreto n. 99.710/9937. Essa convenção motivaria a promulgação, não muito tempo depois, da Lei n. 8.069, de 13 de julho de 1990 - o Estatuto da Criança e do Adolescente $(\mathrm{ECA})^{38}$-, que possui subseções próprias para

Portal da Legislação do Governo Federal. Disponível em: http://legislacao.planalto.gov. br/legisla/legislacao.nsf/Viw_Identificacao/lei\%203.071-1916?OpenDocument>. Acesso em: 27 de outubro de 2017.

34 BRASIL. Uniāo. Lei n. 883, de 21 de outubro de 1949, que dispõe sobre o reconhecimento de filhos ilegitimos. Rio de Janeiro: Congresso Nacional, 1949 (ano da publicação originária). Disponível em: <http://www.planalto.gov. br/ccivil_03/leis/1930-1949/L0883.htm>. Acesso em: 11 de fevereiro de 2018.

35 BRASIL, CF/88, op. cit.

36 CC/1916, "Art. 326. Sendo o desquite judicial, ficarão os filhos menores com o conjugue inocente. $\$ 1^{\circ}$ Se ambos forem culpados, a mãe terá direito de conservar em sua companhia as filhas, enquanto menores, e os filhos até a idade de seis anos. $\$ 2^{\circ}$ Os filhos maiores de seis anos serão entregues à guarda do pai”, op. cit.

37 BRASIL. União. Decreto n. 99.710, de 21 de novembro de 1990, que promulga a Convenção sobre os Direitos da Criança. Brasília: Presidência da República, 1990 (ano da publicação originária). Disponível em: <http://www.planalto.gov. br/ccivil_03/decreto/1990-1994/d99710. $\mathrm{htm}>$. Acesso em: 18 de fevereiro de 2018.

38 BRASIL. União. Lei n. 8.069, de 13 de julho de 1990, que dispóe sobre o Estatuto da Criança e do Adolescente (ECA). Brasília: Congresso Nacional, 1990 (ano da publicação originária). Disponível em: <http://www.planalto.gov. br/Ccivil_03/leis/L8069.htm>. Acesso em: 17 de fevereiro de 2018. 
a guarda, a tutela e a adoção. Há de se lembrar que o ECA tornou o reconhecimento do Estado de filiação um "direito personalíssimo, indisponível e imprescritível, podendo ser exercitado contra os pais ou seus herdeiros" 39 .

O próximo marco legislativo no assunto de filiação e parentesco foi a Lei n. 8.560, de 29 de dezembro de 1992, que dispôs sobre a investigação de paternidade dos filhos havidos fora do matrimônio ${ }^{40}$. Dentre outras medidas, essa lei deu ao Ministério Público legitimidade para ajuizar ação de investigação de paternidade, independentemente de iniciativa do interessado ${ }^{41}$, bem como, após alteração legislativa em 2009, permitiu que todos os meios de prova lícitos valessem na ação de investigação, mas sobretudo o exame de código genético (DNA), cuja recusa na realização por parte do réu gera presunção iuris tantum de paternidade ${ }^{42}$.

Finalmente, o Código Civil de 2002 alterou completamente o tratamento das ações que discutissem a guarda. $\mathrm{O}$ art. $1.583, \$ 2^{\circ}$, do CC/2002, passou a determinar que a guarda seria atribuída ao genitor que revelasse melhores condições de exercê-la, considerados certos fatores de interesse para o menor. Essa alteração já estava em conformidade com a Constituição Federal pois, conforme já visto, ela possibilitara o divórcio ou separação sem discussão de culpa. Após, em reforma realizada nessa parte do Código Civil em 2008, trouxe-se a possibilidade de haver a guarda compartilhada (que hoje é a regra), prevista no art. 1.583 e parágrafos, sendo que a guarda unilateral será atribuída, conforme diz o art. $1.584^{43}$, a quem

39 Conforme art. 27, caput, do ECA, Ibidem.

40 BRASIL. União. Lei n. 8.560, de 29 de dezembro de 1992, que regula a investigação de paternidade dos filhos havidos fora do casamento. Brasília: Congresso Nacional, 1992 (ano da publicação originária). Disponível em: <http://www.planalto.gov. br/CCivil_03/leis/L8560.htm>. Acesso em: 19 de fevereiro de 2018.

41 Lei n. 8.560 , art. $2^{\circ}, " \$ 4^{\circ}$ Se o suposto pai não atender no prazo de trinta dias, a notificação judicial, ou negar a alegada paternidade, o juiz remeterá os autos ao representante do Ministério Público para que intente, havendo elementos suficientes, a ação de investigação de paternidade", Ibidem.

42 "Art. 2o-A. Na ação de investigação de paternidade, todos os meios legais, bem como os moralmente legítimos, serão hábeis para provar a verdade dos fatos. (Incluído pela Lei n. 12.004, de 2009). Parágrafo único. A recusa do réu em se submeter ao exame de código genético DNA gerará a presunção da paternidade, a ser apreciada em conjunto com o contexto probatório. (Incluído pela Lei n. 12.004, de 2009)", Ibidem.

43 "Art. 1.584. A guarda, unilateral ou compartilhada, poderá ser: (Redação dada pela Lei n. 11.698, de 2008). I - requerida, por consenso, pelo pai e pela mãe, ou por qualquer deles, em ação autônoma de separação, de divórcio, de dissolução de união estável ou em medida cautelar; (Incluído pela Lei n. 11.698, de 2008). II - decretada pelo juiz, em atenção a necessidades específicas do filho, ou em razão da distribuição de tempo necessário ao convívio deste com o pai e com a mãe. (Incluído pela Lei n. 11.698, de 2008)”. 
melhor atenda as necessidades específicas do filho. Portanto, em uma ação de guarda atual o assunto principal é o melhor interesse da criança, e não quem fez aquilo ou não fez aquilo outro, ou quem tem ou não culpa.

\section{CONCLUSÃO}

De todo o exposto, verifica-se desde logo que as concepções de família adotadas em um século e em outro são absolutamente incompatíveis. As pessoas que viviam no início do século $\mathrm{XX}$ achariam absurdas as entidades familiares com as quais convivemos hoje e, em equivalente medida, as pessoas que vivem hoje julgariam inadmissível a família que existia nos anos vinte do século precedente.

Tudo isso contribui para o entendimento de que o Direito de Família é um ramo muito dinâmico, em movimento bastante acelerado quando comparado a outras áreas do Direito. Suas alterações buscam refletir os interesses e costumes de um povo. Dentre os aspectos a se considerar para que uma pessoa seja feliz, o seu envolvimento com sua família é um dos mais importantes. Tendo em vista que a própria fugacidade da felicidade enquanto conceito, e da própria sociedade volúvel e gasosa em que vivemos, era de se esperar que o Direito de Família exigisse um empenho maior dos juristas para ver-se atualizado enquanto conjunto de normas representativas dos costumes e anseios de um povo. Nesse sentido, há muito o que evoluir, e sempre haverá. Porém, ao mesmo tempo, considerando todas as mudanças ocorridas até este momento, muitas das quais mencionadas neste artigo, acredito que os juristas de família do Brasil podem olhar para trás e, ao fazê-lo, sentirem-se orgulhosos. E é assim que eu me sinto.

\section{REFERÊNCIAS}

AFONSO DA SILVA, Virgílio. A constitucionalização do direito: os direitos fundamentais nas relações entre particulares. São Paulo: Malheiros, 2014.

BARRETO, Luciano Silva. Evolução histórica e legislativa da família. Série Aperfeiçoamento de Magistrados, n. 13 - 10 Anos do Código Civil - Aplicação, Acertos, Desacertos e Novos Rumos, v. I. [s.l.: s.n.], 2012?

BEVILÁQUA, Clóvis. Code civil des Éstats-Unis du Brésil; traduit et annoté par P. Goulé, C. Daguin e G. D’Ardenne de Tizac, Paris, Nationale, 1928, n. 29, p. 48-49 In: MOREIRA ALVES, José Carlos. Panorama do direito civil brasileiro: das origens aos dias atuais. Revista de Direito da Faculdade de Direito da Universidade de São Paulo (FADUSP). São Paulo: FADUSP, 1990? Disponível em: <http://www.revistas.usp.br/rfdusp/article/viewFile/67220/69830>. Acesso em: 18 de fevereiro de 2018.

BEVILAQUA, Clóvis. Código Civil dos Estados Unidos do Brasil (CC/1916), comentado por Clovis Bevilaqua. Edição histórica. Rio de Janeiro: Ed. Rio, 1973. 
BEVILAQUA, Clovis. Em defesa do projecto de Código Civil brazileiro. São Paulo: Livraria Francisco Alves, 1906.

BRASIL. (União). Lei n. 10.406, de 10 de janeiro 2002 [CC/2002 - Código Civil]. Brasilia: Congresso Nacional, 2002 [ano da publicação originária]. Disponível in Portal da Legislação do Governo Federal. 2002. Disponível em: <http://www.planalto.gov. br/ccivil_03/leis/2002/L10406.htm>. Acesso em: 19 de junho de 2017.

BRASIL. Constituição da República Federativa do Brasil de 1967 (CF/67). Brasília: Constituinte, 1967 (ano da publicação originária). Disponível em: <http://www.planalto.gov. br/ccivil_03/constituicao/constituicao67.htm>. Acesso em: 08 de fevereiro de 2018.

BRASIL. Constituição da República Federativa do Brasil de 1988 [CF/88]. Brasília: Congresso Nacional (Poder Constituinte), outubro de 1988. Disponível no Portal da Legislação do Governo Federal: Disponível em: <http://www.planalto.gov. br/ccivil_03/constituicao/constituicao.htm>. Acesso em: 11 de julho de 2017.

BRASIL. Emenda Constitucional (EC) n. 9, de 28 de junho de 1977. Brasília: Mesas da Câmara dos Deputados e do Senado Federal, 1977 (ano da publicação originária). Disponível em: <http://www.planalto.gov. br/ccivil_03/constituicao/Emendas/Emc_anterior1988/emc09-77.htm>. Acesso em: 18 de fevereiro de 2018.

BRASIL. Supremo Tribunal Federal (STF). Recurso Extraordinário (RE) n. 646.721/RS. Relator: Ministro Marco Aurélio de Mello; Relator para o acórdão: Ministro Roberto Barroso. Brasília: STF, 11 de setembro de 2017. Disponível em: <http://www.stf.jus.br/ portal/jurisprudencia/listarJurisprudencia.asp?s1=\%28646721\%2ENUME\%2E+OU+ 646721\%2EACMS\%2E\%29\&base=baseAcordaos \&url=http://tinyurl.com/j9y92gj>. Acesso em: 18 de fevereiro de 2018.

BRASIL. Supremo Tribunal Federal (STF). Recurso Extraordinário (RE) n. 878.694/MG. Relator: Ministro Roberto Barroso. Brasília: STF, 6 de fevereiro de 2018. Disponível em: <http://www.stf.jus.br/portal/jurisprudencia/listarJurisprudencia.asp?s1=\%28878694 \%2ENUME\%2E+OU+878694\%2EACMS\%2E\%29\&base=baseAcordaos \&url = http://tinyurl.com/he2a4o4>. Acesso em: 18 de fevereiro de 2018.

BRASIL. União. Constituição da República dos Estados Unidos do Brasil, de 24 de fevereiro de 1891. Rio de Janeiro: Congresso Constituinte, 1891 (data da publicação originária). Disponível em: <https://legislacao.planalto.gov. br/legisla/legislacao.nsf/viwTodos/4ed91893 cbdd0e10032569fa0074213f? OpenDocument \&Highlight=1, \&AutoFramed $>$. Acesso em: 10 de fevereiro de 2018.

BRASIL. União. Decreto n. 181, de 24 de janeiro de 1890. Rio de Janeiro: Governo provisório da República dos Estados Unidos do Brasil, 1890 (ano da publicação originária). Disponível em: <http://www2.camara.leg.br/legin/fed/decret/1824-1899/decreto-181-24-janeiro-1890-507282-publicacaooriginal-1-pe.html>. Acesso em: $10 \mathrm{de}$ fevereiro de 2018.

BRASIL. União. Decreto n. 99.710, de 21 de novembro de 1990, que promulga a Convenção sobre os Direitos da Criança. Brasília: Presidência da República, 1990 (ano da publicação 
originária). Disponível em: <http://www.planalto.gov. br/ccivil_03/decreto/1990-1994/ d99710.htm>. Acesso em: 18 de fevereiro de 2018.

BRASIL. União. Lei n. 3.071, de $1^{\circ}$ de janeiro de 1916 [CC/1916 - Código Civil]. Brasilia: Congresso Nacional, 1916 [ano da publicação originária]. Disponível in Portal da Legislação do Governo Federal. Disponível em: http://legislacao.planalto.gov. br/legisla/ legislacao.nsf/Viw_Identificacao/lei\%203.071-1916?OpenDocument>. Acesso em: $27 \mathrm{de}$ outubro de 2017

BRASIL. União. Lei n. 4.121, de 27 de agosto de 1962, que dispõe sobre a situação jurídica da mulher casada. Brasília: Congresso Nacional, 1962 (data da publicação originária). Disponível em: <http://www.planalto.gov. br/Ccivil_03/leis/1950-1969/L4121.htm\#art1>. Acesso em: 9 de fevereiro de 2018.

BRASIL. União. Lei n. 6.515, de 26 de dezembro de 1977, que regula os casos de dissolução da sociedade conjugal e do casamento, seus efeitos e respectivos processos e dá outras providências. Brasília: Congresso Nacional, 1977 (ano da publicação originária). Disponível em: $<$ http://www.planalto.gov. br/ccivil_03/leis/16515.htm>. Acesso em: 14 de fevereiro de 2018.

BRASIL. União. Lei n. 8.069, de 13 de julho de 1990, que dispóe sobre o Estatuto da Criança e do Adolescente (ECA). Brasília: Congresso Nacional, 1990 (ano da publicação originária). Disponível em: <http://www.planalto.gov. br/Ccivil_03/leis/L8069.htm>. Acesso em: 17 de fevereiro de 2018.

BRASIL. União. Lei n. 8.560, de 29 de dezembro de 1992, que regula a investigação de paternidade dos filhos havidos fora do casamento. Brasília: Congresso Nacional, 1992 (ano da publicação originária). Disponível em: <http://www.planalto.gov. br/CCivil_03/leis/ L8560.htm>. Acesso em: 19 de fevereiro de 2018

BRASIL. União. Lei n. 883, de 21 de outubro de 1949, que dispõe sobre o reconhecimento de filhos ilegitimos. Rio de Janeiro: Congresso Nacional, 1949 (ano da publicação originária). Disponível em: <http://www.planalto.gov. br/ccivil_03/leis/1930-1949/L0883. htm >. Acesso em: 11 de fevereiro de 2018.

HIRONAKA, Giselda Maria Fernandes Novaes. Morrer e suceder: passado e presente da transmissão sucessória concorrente. 2. ed. rev. São Paulo: RT, 2014.

MOREIRA ALVES, José Carlos. Panorama do direito civil brasileiro: das origens aos dias atuais. Revista de Direito da Faculdade de Direito da Universidade de São Paulo (FADUSP). São Paulo: FADUSP, 1990? Disponível em <http://www.revistas.usp.br/rfdusp/article/ viewFile/67220/69830>. Acesso em: 18 de fevereiro de 2018.

PERLINGIERI, Pietro. O direito civil na legalidade constitucional. Tradução de Maria Cristina De Cicco. Rio de Janeiro: Renovar, 2008.

TEPEDINO, Gustavo; BARBOZA, Heloisa Helena; MORAES, Maria Celina Bodin de. Código Civil interpretado conforme a Constituição da República. 2. ed. rev. e atual. Rio de Janeiro: Renovar, 2007. 